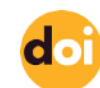

http://doi.org/10.22282/ojrs.2021.79

\title{
COMPARISON OF SPORTS SCIENCE STUDENTS' ATTITUDES TOWARDS THE EDUCATION OF PERSONS WITH DISABILITIES AND THEIR ATTITUDES TOWARDS INTERNATIONAL SPORTS ORGANIZATIONS
}

\author{
*Ilker GÜNEL, *Mihriay MUSA, *Abdurrahman KEPOGLU*, \\ *Suzan Tuğçe TATAR, **Cihad KISA
}

* Faculty of Sport Science, Usak University, USAK

** Dokuz Eylül University İzmir, TURKEY

\begin{abstract}
The aim of this study is to compare the attitudes of students studying in sports sciences towards education of disabled individuals and towards international sports organizations. The target population of this study, which is carried out by relational screening method, one of the quantitative research designs, consists of students studying at the Coaching Department of the Faculty of Sport Sciences at Uşak University. The sample of the study, which was determined by the convenience sampling method, one of the nonprobability sampling methods, is composed of 116 students, 97 of them are male and 19 of them are female, studying at Uşak University, Faculty of Sport Sciences, Coaching Department. The data were

Education of Disabled Individuals" and the "Attitude Scale towards International Sports Organizations". Since the data are suitable for normal distribution, parametric tests, $\mathrm{t}$ test, one-way ANOVA and multiple regression analysis were used in the study. As a result, it can be said that students studying at the faculty of sports sciences generally have high attitudes towards the education of disabled individuals and towards international sports organizations. It can be stated that the disabled individuals are given the right to education and their belief in the results of this training is positive, that the disabled individuals have a positive feeling about their participation in international sports organizations and their courage in this direction has increased.
\end{abstract} collected using the "Attitude Scale for the

Key Words Individuals with Disabilities, Education, International Sports Organization 


\section{INTRODUCTION}

It is not their preferred situation for people with disabilities to be born with disabilities. Of course, in this paradigm, bringing a disabled person into the world is not the choice of their parents. According to recent research, there are about 8 million disabled people living in our country (Sezer, 2012). Definitions of disabled people in the literature include information such as "abnormal, disabled and needy". But it can be quite difficult to make a general definition for these individuals. However, in some institutions and organizations, the definitions regarding the disabled are unfortunately included in this scope. Generally speaking, the word "disabled" is widely used. (Çevik and Kabasakal, 2013). There may also be some disadvantages experienced by disabled individuals in social conditions. The most important of these is the problem of marginalization. This situation not only puts the lives of people with disabilities in a more difficult situation, but they may encounter problems such as being excluded from social life (Gençtürk and Korkut, 2020). A common definition of disability can be defined as a condition in which the individual is below the established limits or has a deficiency (Whyte \& Benedicte, 1995). Although everyone has the right to an equal education in Turkey, people with disabilities are deprived of these rights (Şahin,2012). Education is the most important condition for the inclusion of disabled people in society and for them to have a say in society. All opportunities for disabled people in Turkey and the world should be presented equally with regard to the right to education without any privileges (Şişman, 2014). Education and training have an important place for everyone, while this condition is even more important for individuals who have lost their body functions at birth or later. Therefore, participation of individuals with disabilities in educational activities is an important opportunity for them to develop aspects that they feel are missing and to continue their lives as an equipped individual (Sevinç and Çay, 2017). In this context, it is known that it is of great importance in its sports activities. Individuals with disabilities can improve physical health and improve quality of life by participating in sports activities (Wu et al.,2017). The participation rate of disabled individuals in sports may reflect the development level of disabled sports to some extent. It is an important indicator to evaluate the level of social civilization. Most countries and regions have agreed to increase participation of individuals with disabilities in sports activities as an important starting point for raising the level of social civilization, and strongly develop sports for individuals with disabilities (Wu and Huang, 2015). Disabled individuals have limited 
conditions and face many challenges in sporting activities (Shields et al., 2014;Jaarsmia et al., 2017). In order to be able to exhibit positive behavior in sports activities, they must overcome both physical and psychological pressures. They are affected by constraints on external factors such as material conditions, living environment, level of education. Some people with disabilities may not know that participating in sporting activities can support improving body function (Martin, 2013). Some disabled people do not have proper sports facilities (Sa, 2012; Sahlin, 2015). There are misunderstandings in the understanding of disabled individuals regarding sports activities. They believe that participation in physical activities, such as housework and agricultural labor, is equivalent to participation in sporting activities, and no additional participation in sports is required. As a result, the enthusiasm of persons with disabilities to participate in sports activities is not sufficient, and therefore, disabled individuals are prevented from improving their physical functions since they do not participate in sports activities. Chronic diseases are the main cause of disability in the elderly and this is the main reason for the increase in global disability estimates (Qiu, 2013; World Health Organization, 2013) Participating in sports activities is one of the effective ways to slow the spread of chronic diseases (Calonge, 2017) and participating in sports activities has become the center of attention in the fields of rehabilitation sciences and sports sciences. Sports is a complex of complexes that bring individuals together, unite and enable them to act in a unified whole. Organizing sports organizations contributes to the consolidation of peace, brotherhood and friendship in the international arena (Tek, 2006). Every sporting activity is a social experience for individuals with disabilities. Individuals with disabilities who are engaged in any branch of sport have positive self-confidence and compliance with their environment (Tekkurşun and İlhan 2020). The aim of this study is to examine the attitudes of sports science students regarding the education of disabled people and their attitudes towards international sports organizations.

\section{METHOD}

The aim of this study was to examine the attitudes of sports science students regarding the education of individuals with disabilities and the attitudes towards international sports organizations, so the study was carried out by relational screening method from quantitative research patterns. Since the attitudes of sports science students towards the education of disabled individuals and their attitudes towards international organizations are not clear, this 
research design was considered appropriate. The target population of the research consists of students studying at Uşak University Faculty of Sport Sciences. The sample of the study was chosen using the simple random sampling method, one of the simple probability-based sampling methods. It consists of 117 students according to $95 \%$ confidence interval and 5\% margin of error. Since it is suitable for the purpose of the study, the "Attitude towards the Education of Persons with Disabilities" scale, whose validity and reliability was conducted by Kösterelioğlu (2013), was used as a data collection tool. It has been prepared as "right to education", "dissemination of education", "belief about its results", "investment in special education field" and "voluntary participation" and it is a 5-point Likert-type scale which is answered as 1 strongly disagree 5 strongly agree. The second scale is the "Attitude Towards International Sports Organizations" scale, whose validity and reliability was conducted by Aktaş and Kan (2018). It is a 5-point Likert-type scale with 20 items and 3 sub-dimensions: "positive emotion", "negative emotion" and "behavioral", with 1 strongly disagree and 5 strongly agree. The Cronbach Alpha coefficient, which is the reliability of the scale, was determined as $\alpha=, 91$. The Cronbach Alpha coefficient, which is the reliability of the scale, was determined as $\alpha=.92$. It can be said that the internal consistency of the scales used has a high level of reliability. As a result of the normality analysis of the data, it was determined that the data corresponds to the normal distribution. Since the data is normally distributed, it was decided to perform parametric analysis.

Table 1.Descriptive Statistics For Participants

\begin{tabular}{llcc}
\hline Variables & Groups & $\mathbf{N}$ & $\mathbf{\%}$ \\
\hline \multirow{2}{*}{ Gender } & Female & 19 & 16,4 \\
& Male & 97 & 83,6 \\
\cline { 2 - 4 } Sport Level & Professional & 4 & 3,4 \\
& National & 2 & 1,7 \\
& Amateur & 70 & 60,3 \\
& Other & 40 & 34,5 \\
& Total & 116 & 100 \\
\hline
\end{tabular}


As seen in Table 1, 16.4\% of the participants are female and $83.6 \%$ are male students. $60.3 \%$ of the participants are amateur, $3.4 \%$ of the participants are professional, $1.7 \%$ of the participants are national athletes, and $34.5 \%$ of the participants are other athletes.

Table 2. Descriptive Statistics of the Participants

\begin{tabular}{lccc}
\hline Scales & $\mathbf{N}$ & $\overline{\boldsymbol{x}}$ & ss \\
\hline USOYTÖ & 116 & 67,46 & 6,79 \\
EBEYTÖ & 116 & 67,59 & 7,13
\end{tabular}

USO: Attitude Scale towards International Sports Organizations; ;EBE: Attitude Scale for the Training of Individuals with Disabilities

As seen in Table 2, it was found that disabled individuals have high attitudes towards education and $(\overline{\boldsymbol{x}}=\mathbf{6 7 , 5 9} \pm \mathbf{7 , 1 3})$, and their attitudes towards international sports organizations are high $(\bar{x}=67,46 \pm 6,79)$.

Table 3.Analysis of the Differences in Average Scores of Students from the Scales by Gender

\begin{tabular}{|c|c|c|c|c|c|c|c|c|c|}
\hline \multirow[b]{2}{*}{ Variables } & \multirow[b]{2}{*}{ Gender } & \multirow[b]{2}{*}{$\mathrm{n}$} & \multirow[b]{2}{*}{$\bar{x}$} & \multirow[b]{2}{*}{$\mathrm{sd}$} & \multicolumn{2}{|c|}{ Levene Test } & \multirow[b]{2}{*}{$\mathrm{df}$} & \multirow[b]{2}{*}{$\mathrm{t}$} & \multirow[b]{2}{*}{$\mathrm{p}$} \\
\hline & & & & & $\mathrm{F}$ & $\mathrm{p}$ & & & \\
\hline \multirow{2}{*}{ USOYTÖ General } & Female & 19 & 65,74 & 4,39 & & & \multirow{4}{*}{114} & \multirow{2}{*}{$-, 1,217$} & \multirow{2}{*}{0,226} \\
\hline & Male & 97 & 67,80 & 7,13 & 2,000 & 0,093 & & & \\
\hline \multirow{2}{*}{ EBEYTÖ General } & Female & 19 & 66,84 & 4,26 & \multirow{2}{*}{2,214} & \multirow{2}{*}{0,140} & & \multirow{2}{*}{$-, 0,496$} & \multirow{2}{*}{0,621} \\
\hline & Male & 97 & 67,73 & 7,58 & & & & & \\
\hline
\end{tabular}

p>0,05; USOYYÖ: International Sports Organizations Attitude Scale; EBEYTÖ: Attitude Scale towards the Education of Disabled Individuals

As seen in Table 3, no statistically significant difference was determined between the students' attitudes towards international sports organizations $(p=, 226 ; p>0.05)$ and their attitudes towards the education of disabled individuals $(\mathrm{p}=, 661 ; \mathrm{p}>0.05)$ and their gender. 
Table 4.The Average Scores of Students from the Scales and Analysis of Differences Regarding Their Sports Level

\begin{tabular}{|c|c|c|c|c|c|c|c|}
\hline Scales & Sports Level & $\mathrm{n}$ & $\bar{x}$ & sd & $\mathrm{df}$ & $\mathrm{F}$ & $\mathrm{p}$ \\
\hline \multirow{4}{*}{ EBEYTÖ General } & Professional & 4 & 71,75 & 0,50 & & \multirow{4}{*}{0,671} & \multirow{4}{*}{0,571} \\
\hline & National & 2 & 68,50 & 0,71 & 3 & & \\
\hline & Amateur & 70 & 67,03 & 7,06 & 112 & & \\
\hline & Other & 40 & 68,10 & 7,70 & & & \\
\hline \multirow{4}{*}{ USOYYÖ General } & Professional & 4 & 68,00 & 8,64 & & \multirow{4}{*}{2,013} & \multirow{4}{*}{0,116} \\
\hline & National & 2 & 73,50 & 2,12 & 3 & & \\
\hline & Amateur & 70 & 68,34 & 5,73 & 112 & & \\
\hline & Other & 40 & 65,58 & 8,05 & & & \\
\hline
\end{tabular}

As seen in Table 4, there was no statistically significant difference between the students' attitudes towards international sports organizations $(\mathrm{p}=, 571 ; \mathrm{p}>0.05)$ and their attitudes towards the education of disabled individuals $(\mathrm{p}=, 116 ; \mathrm{p}>0.05)$ and their sports levels.

Table 5.Analysis of Students on the Effect of Attitude Scale towards the Education of Disabled Individuals and Sub-Dimensions on Positive Emotion

\begin{tabular}{|c|c|c|c|c|c|c|}
\hline \multirow[t]{2}{*}{ Independent variables } & \multicolumn{2}{|c|}{$\begin{array}{l}\text { Unstandardized } \\
\text { Coefficients }\end{array}$} & \multirow{2}{*}{$\begin{array}{c}\begin{array}{c}\text { Standardized } \\
\text { Coefficients }\end{array} \\
\beta\end{array}$} & \multirow[b]{2}{*}{$\mathbf{t}$} & \multirow[b]{2}{*}{$p$} & \multirow[b]{2}{*}{ VIF } \\
\hline & $\mathbf{B}$ & SH & & & & \\
\hline (Constant) & 24,815 & 3,588 & & 6,917 & 0,000 & \\
\hline The Right to Education & $-0,496$ & 0,219 & $\mathbf{0 , 3 5 0}$ & $-2,268$ & $\mathbf{0 , 0 2 5 *}$ & 3,381 \\
\hline Belief in Education Outcomes & $-0,49$ & 0,185 & 0,263 & $-2,643$ & $0,009 *$ & 1,406 \\
\hline Investment in Special Education & $-0,014$ & 0,261 & $-0,007$ & $-0,055$ & 0,956 & 2,448 \\
\hline Volunteer Participation & 0,09 & 0,297 & 0,041 & 0,302 & 0,763 & 2,657 \\
\hline EBEYTÖ Total & 0,294 & 0,136 & 0,499 & 2,163 & $\mathbf{0 , 0 3 3 *}$ & 7,577 \\
\hline $\mathrm{R}=, 476$ & $\mathrm{R}^{2}=, 191$ & & & & & \\
\hline$F(5-110)=6,446$ & $\mathrm{p}=0,000$ & \multicolumn{2}{|c|}{ Durbin Watson = 1,574 } & & & \\
\hline
\end{tabular}

As seen in Table 5, it has been determined that the model established on the positive emotion sub-dimension of the attitude scale towards international sports organizations of 
students' attitudes towards the education of disabled individuals is significant $\left(\mathrm{F}_{(5-}\right.$ $110)=6,446 ; p=0,000 ; p<0,001)$. When the coefficient values of regression are examined, the right to education has a significant positive effect on positive emotion $(\boldsymbol{\beta}=0,35 ; \mathrm{p}=0,025)$. Their attitudes towards educational outcomes have a significant positive effect on positive emotion. $(\boldsymbol{\beta}=0,26 ; \mathrm{p}=0,009)$. Disabled individuals' attitudes towards their education have a significant positive effect. ( $\boldsymbol{\beta}=-0,49 ; \mathrm{p}=0,033)$. On the other hand, no significant effect of special education field and volunteer participation sub-dimensions on positive emotion was determined.

Table 6.Analysis of Students' Effects of Attitude Scale towards the Education of Disabled Individuals and Sub-Dimensions on Negative Emotion

\begin{tabular}{lccccccc}
\hline \multirow{2}{*}{ Independent variables } & \multicolumn{2}{c}{$\begin{array}{c}\text { Unstandardize } \\
\text { d Coefficients }\end{array}$} & $\begin{array}{c}\text { Standardized } \\
\text { Coefficients }\end{array}$ & & & \\
\cline { 2 - 5 } & $\mathbf{B}$ & $\mathbf{S H}$ & $\boldsymbol{\beta}$ & $\mathbf{t}$ & $\boldsymbol{p}$ & VIF \\
\hline (Constant) & 7,798 & 3,22 & & 2,422 & 0,017 & \\
The Right to Education & 0,873 & 0,196 & $-0,624$ & 4,446 & $\mathbf{0 , 0 0 0} * *$ & 3,381 \\
Belief in Education Outcomes & 0,821 & 0,166 & $-0,447$ & 4,933 & $\mathbf{0 , 0 0 0 * *}$ & 1,406 \\
Belief in the Field of Special & 0,101 & 0,234 & 0,052 & 0,432 & 0,667 & 2,448 \\
Education & & & & & & \\
Volunteer Participation & 0,218 & 0,266 & 0,102 & 0,818 & 0,415 & 2,657 \\
EBEYTÖ & $-0,373$ & 0,122 & $-0,644$ & $-3,065$ & $\mathbf{0 , 0 0 3} * *$ & 7,577 \\
\hline R= 59 & & & & & &
\end{tabular}

$\mathrm{R}=, 59 \quad \mathrm{R}^{2}=, 32$

$\mathrm{F}(5-110)=12,295 \quad \mathrm{p}=0,000 \quad$ Durbin Watson $=1,574$

Dependent Variable: Negative Emotion Component; ${ }^{*} \mathrm{p}<0,05$, EBEYTÖ: Standardized Beta Values Were Used

Attitude Scale towards the Education of Disabled Individuals

As seen in Table 6, it was determined that the model built on the positive emotion subdimension of the attitude scale towards international sports organizations of students' attitudes towards the education of individuals with disabilities is significant $\left(\mathrm{F}_{(5-}\right.$ $110)=12,295 ; \mathrm{p}=0,000 ; \mathrm{p}<0,001)$. When the coefficient values regarding the regression are examined, the right to education has a significant negative effect on negative emotion $(\boldsymbol{\beta}=-$ 0,62; $\mathrm{p}=0,000)$. Belief in Education Outcomes has a significant negative effect on negative emotion towards international sports organizations. $(\boldsymbol{\beta}=-0,44 ; \mathrm{p}=0,000)$. Disabled individuals' attitudes towards their education have a significant negative effect. $(\boldsymbol{\beta}=-0,64 ; \mathrm{p}=0,033)$. On the 
other hand, no significant effect of special education field and volunteer participation subdimensions on negative emotion was determined.

Table 7.Analysis of Students' Effects of Attitude Scale towards the Education of Disabled Individuals and Sub-Dimensions on Behavioral

\begin{tabular}{|c|c|c|c|c|c|c|}
\hline \multicolumn{7}{|c|}{ Unstandardized } \\
\hline \multirow[t]{2}{*}{ Independent variables } & \multicolumn{2}{|c|}{ Coefficients } & \multicolumn{3}{|c|}{ Standardized Coefficients } & \multirow[b]{2}{*}{ VIF } \\
\hline & $\mathbf{B}$ & SH & $\bar{\beta}$ & $\mathbf{t}$ & $\mathbf{p}$ & \\
\hline (Constant) & 12,985 & 4,637 & & 2,8 & 0,006 & \\
\hline The Right to Education & $-0,429$ & 0,283 & $-0,242$ & $-1,517$ & 0,132 & 3,381 \\
\hline Belief in Education Outcomes & 0,169 & 0,24 & 0,072 & 0,704 & 0,483 & 1,406 \\
\hline \multicolumn{7}{|l|}{ Belief in the Field of Special } \\
\hline Education & 0,229 & 0,337 & 0,092 & 0,678 & 0,499 & 2,448 \\
\hline Volunteer Participation & 0,54 & 0,383 & 0,199 & 1,408 & 0,162 & 2,657 \\
\hline EBEYTÖ Total & 0,184 & 0,175 & 0,25 & 1,05 & 0,296 & 7,577 \\
\hline $\mathrm{R}^{2}=, 13$ & & & & & & \\
\hline$F(5-110)=4,637$ & \multicolumn{5}{|c|}{ Durbin Watson $=1,877$} & \\
\hline
\end{tabular}

When Table 7 is examined, it has been determined that the students' attitudes towards the education of persons with disabilities and the model built on the behavioral sub-dimension of the international sports organizations attitude scale are significant $\left(\mathrm{F}_{(5-}\right.$ $110)=4,637 ; \mathrm{p}=0,000 ; \mathrm{p}<0,001)$. However, when the coefficient values related to regression are examined, there is no significant effect of the right to education, Belief on Educational Outcomes, special education field and voluntary participation on the behavioral sub-dimension.

\section{DISCUSSION}

In this study, which is carried out with the relational scanning method, one of the quantitative research designs, it is aimed to examine the attitudes of students studying in sports sciences towards the education of disabled individuals and attitudes towards international sports organizations. In the study, it was determined that the attitudes of disabled people towards education and their attitudes towards international sports organizations were also high. 
According to this result, it can be said that students are sensitive and thoughtful about the education of people with disabilities and their participation in international sports organizations (Table 2).

No significant differences were found between the attitudes of students towards the education of individuals with disabilities and participation in international sports organizations and their gender (Table 3). Looking at the literature, studies that are similar to our study have been found (Sar1, Bozgeyikli, 2017) found no significant difference between the attitudes of disabled individuals towards education and their gender. There are also studies that differ from the results of our study. (Kıran and Dengiz, 2019; Gençtürk and Korkut, 2020) found a significant difference in favor of women between the attitudes of psychological counselors towards the education of disabled individuals and the gender variable. Uçar et al. (2019) found a significant difference in favor of males between the attitudes of teachers studying in different branches towards the education of disabled individuals and their gender.

In our study, the right to education and belief in the results of education, which are subdimensions of students' attitudes towards the education of persons with disabilities, have a significant effect on the positive emotion of disabled individuals to participate in the international sports organization. According to this result, it can be said that students' attitudes towards giving disabled individuals the right to education will positively increase positive feelings in the orientation to international sports organizations. (Table 3).

The right to education and belief in the results of education, which are sub-dimensions of students' attitudes towards the education of persons with disabilities, have a negative and significant effect on the positive emotion of disabled individuals to participate in the international sports organization. According to this result, it can be said that students' attitudes towards giving disabled individuals the right to education have a decreasing effect on negative feelings towards international sports organizations. However, in our study, no significant effect of the sub-dimensions of the attitudes towards education of persons with disabilities was found on the behavioral sub-dimension. Although there are many studies in the literature on attitudes towards the education of disabled individuals, no study has been found on the attitudes of persons with disabilities towards participation in an international sports organization. Considering from this point of view, it can be said that our study is qualified to fill the gap in the literature. 


\section{CONCLUSION}

Looking at our research, it can be stated that the attitudes of students studying at the faculty of sports sciences towards the education of disabled individuals and towards international sports organizations are positively high in our study on the attitudes of students studying in sports science regarding the education of individuals with disabilities and their attitudes towards international sports organizations. It has been observed that when disabled individuals are given the right to education, their belief in the results of this training is positive, that disabled individuals have a positive feeling for their participation in international sports organizations and their courage in this direction increases.

\section{REFERENCES}

Sezer, F. (2012). Preventıve Gu1dance Work Towards People With Disabılitıes To Developıng A Positıve Attıtude; An Experımental Applicatıon, Education Sciences, 7(1), 16-26.

Çevik, O., \& Kabasakal, K. (2013). Investigation of the effects of sports activities on social cohesion and socialization of people with disabilities, International Journal of Social and Economic Sciences, 3(2), 74-83.

Gençtürk, Z., \& Korkut, G. (2020). Examınatıon of Attıtudes of Unıversıty Students Towards Person With Dısabılıtıes, Bingöl University Journal of Social Sciences Institute, (19), 105-126.

Whyte, Susan Reynolds ve Ingstad, Benedicte (1995), "Disability and Culture: An Overview", (Ed. Benedicte Ingstad ve Susan Reynolds Whyte), Disability and Culture, California: University of California Press, 3-34.

Şahin, M.N. (2021). Design Principles of Educational Buildings for Disabled People and Examining Examples, Unpublished Master's Thesis, Institute of Science, Haliç University, İstanbul.

Şişman, Y. (2014). Equality, Discrimination and the Right to Education for Persons with Disabilities, Social Policies Labor Journal, 32, 57-85.

SEVINÇ, İ., \& ÇAY, Ö. G. M. (2017). Problems of Physıcally Dısabled Persons Faced Durıng Unıversity Educatıon (The Case Study Of Akdenız Unıversity). Selcuk University Journal of Social and Technical Researches, (13), 219-238. 
Tek, T. (2006). Turkey's Problems Faced by Organized by International Federation of Sport Organizations, Unpublished Master's Thesis, Institute of Health Sciences, Selçuk University, Konya.

Tekkurşun, G. \& İlhan, E.L. (2020). Sports Participation Motivation for Disabled Athletes, Ankara University Faculty of Educational Sciences Special Education Journal

Ming, W., Xin, L., Ruo, D.F. (2017) The research process of physical exercise to improve the physical functions of people with disabilities. Chinese Rehabilitation Theory and Practice, 23(3): 315-318.

Wu Sa, Huang Yaling. (2015). Research and Enlightenment on the Development of SelfOrganization in American Sports with Disabilities [J] Beijing Sports University Journal, 38(6): 6-11.

Jaarsma, E. A., Dijkstra, P. U., Geertzen, J. H. B., \& Dekker, R. (2014). Barriers to and facilitators of sports participation for people with physical disabilities: A systematic review. Scandinavian journal of medicine \& science in sports, 24(6), 871-881.

Shields, N., \& Synnot, A. J. (2014). An exploratory study of how sports and recreation industry personnel perceive the barriers and facilitators of physical activity in children with disability. Disability and rehabilitation, 36(24), 2080-2084.

Martin, J. J. (2013). Benefits and barriers to physical activity for individuals with disabilities: a social-relational model of disability perspective. Disability and rehabilitation, 35(24), 20302037.

Sahlin, K. B., \& Lexell, J. (2015). Impact of organized sports on activity, participation, and quality of life in people with neurologic disabilities. PM\&R, 7(10), 1081-1088.

Sá, M. M., Azevedo, R., Martins, M. C., Machado, O., \& Tavares, J. (2012). Accessibility of sports facilities for persons with reduced mobility and assessment of their motivation for practice. Work, 41(Supplement 1), 2017-2023.

Qiu Zhuoying (2013)" Structure, methods and implementation importance of the World Disability Report [J] Chinese Rehabilitation Theory and Practice,19 (10): 901-904. 
Dünya Sağlık Örgütü, Dünya Bankası, (2013). World Disability Report (International Chinese Version) [M]. Qiu Zhuoying, translation. Geneva: World Health Organization,.

JA, C. M. (2017). Physical activity as prevention and treatment resource of chronic diseases in the syllabus of medicine and sport sciences at Spanish universities. Nutricion Hospitalaria, 34(4), 961-968.

Kiran, B., \& Dengiz, G. (2019). Examination of school counselors' attitudes towards the education of disabled individuals according to their gender, experience and self-efficacy. Turkish Psychological Counseling and Guidance Journal, 9(52), 43-67.

Uçar, D. E., Yıldızer, G., Özböke, C., Yılmaz, İ., \& Kocaekşi, S. (2019). An Investigation of Teacher Candidates' Attitudes Towards Special Needs Individuals in Terms of Teaching Branches and Their Gender: The Case of Anadolu University. İnönü University Journal of Physical Education and Sport Sciences, 6(1), 1-13.

Sarı, H. Bozgeyikli, H. (2017). Investigation of Pre-service Teachers' Attitudes towards Disabled Individuals, Selçuk University, Journal of Social Sciences Institute, 17(39), 141-169 